\title{
Visual evidence
}

\author{
Neal Feigenson \\ Quinnipiac University, Hamden, Connecticut
}

\begin{abstract}
Visual and other demonstrative evidence has become increasingly prevalent in American and other courtrooms in recent years. However, there have been relatively few experimental studies of the effects of this kind of evidence in legal settings. As a consequence, little is known about when and how it affects legal decision making. In this article, I survey the extant research, including studies of photographs, videos, computer animations, and PowerPoint displays. The research shows that visual evidence affects legal decisions in some circumstances but not in others. It also indicates that visual evidence sometimes enhances legal judgment by improving recall and understanding but sometimes impairs judgment by prompting undue emotional responses, cognitive and perceptual biases, and/or peripheral processing. The limitations of the research are discussed, and directions for future research are suggested.
\end{abstract}

Visual and other demonstrative evidence, including photographs, drawings, maps, and models, has long been used in court to illustrate the oral testimony of eyewitnesses and experts (Mnookin, 1998). ${ }^{1}$ It has become increasingly prevalent in recent years, in large part because digital technology has made it easier to record or, in the case of computer animations, to recreate legally relevant reality visually (Feigenson \& Spiesel, 2009). A dashboard camera video, for instance, provided the dispositive evidence in a recent Supreme Court decision on the police's authority to use deadly force to terminate a car chase (Scott v. Harris, 2007), ${ }^{2}$ and a cell phone video will be critical should a lawsuit brought against a New York City police officer for assaulting a bicyclist proceed to trial (Weichselbaum, 2009). ${ }^{3}$

Although there have been efforts to document courtroom technology generally (e.g., Center for Legal and Court Technology, 2007) and to instruct judges and lawyers in its use (e.g., Federal Judicial Center/National Institute for Trial Advocacy, 2001), there have been relatively few experimental studies of the effects of visual and multimedia evidence in legal settings. As a consequence, little is known about when and how this kind of evidence affects legal decision making. A better understanding should be not only of intrinsic interest to cognitive psychologists but also extremely useful to the legal system, helping policy makers and judges to regulate the use of such evidence more wisely and informing advocates as they decide when and how to present it.

\section{VARIETIES OF VISUAL EVIDENCE}

There are good reasons to suspect that visual evidence may influence ultimate judgments of guilt or liability and damages. The police officers who beat Rodney King might never have been brought to trial were it not for George Holliday's videotape of the incident, and the jurors' verdict arguably turned on their interpretations of the tape. As surveillance videos made by both governments and private citizens proliferate, such evidence is likely to make a difference in more and more cases (see Feigenson \& Spiesel, 2009). Even where it is not necessarily the focal point of the case, visual evidence would likely influence decision makers' thoughts and feelings and, hence, their verdicts. Because still or moving pictures can be more vivid than oral testimony or text, for instance, visual evidence could well be more memorable and/or lead to stronger emotional responses (see Bell \& Loftus, 1985), either of which could affect the outcome. Personal injury lawyers often present day-in-the-life movies of an accident or malpractice victim (e.g., Joseph, 1997), presumably because they believe that the movies give jurors a better understanding of the extent of the victim's injuries and/ or encourage them to sympathize with the victim, leading to larger damage awards. In short, general cognitive psychological research, the practices of experienced trial lawyers, and perhaps common sense all suggest that visual evidence may often affect legal outcomes.

\section{Experimental Findings}

The experimental findings to date, however, are mixed.

Photographs. Photographic evidence has generally yielded more robust effects than have other media on ultimate judgments. For example, showing participants photos of the accident victim in a negligence case significantly increased damage awards but not measures of the defendant's culpability (Oliver \& Griffitt, 1976; Whalen $\&$ Blanchard, 1982). More recently, showing participants either color or black-and-white explicit autopsy photos (Douglas, Lyon, \& Ogloff, 1997) or either neutral or grue-

N. Feigenson, neal.feigenson@quinnipiac.edu 
some photos of a murder victim (Bright \& GoodmanDelahunty, 2006) significantly increased the proportion of guilty verdicts. In another, unpublished study, participants who saw gruesome photos of a traffic accident victim were significantly likelier to find the defendant driver liable (Bright \& Goodman-Delahunty, 2009). On the other hand, two dissertation studies failed to show any effects of murder victim photographs on participants' verdict preferences or sentencing decisions (Modin, 2006; Nemeth, 2002).

Videos. Two studies in which the presence or absence of video evidence was manipulated as an independent variable - in one, a crime scene walk-through was used (Kassin \& Garfield, 1991); in the other, a video reenactment of an accident was used (Fishfader, Howells, Katz, \& Teresi, 1996) - failed to show any effects on participants' verdicts, on one hand, or on the percentage of liability that they attributed to the plaintiff or their damage awards, on the other.

There are no experimental studies of the effects of surveillance or day-in-the-life videos on legal judgments in which video and no-video conditions have been compared, but correlations have been found between participants' interpretations of surveillance videos and their attitudes and/or demographic characteristics. For instance, mock jurors who supported the death penalty were more likely than those who opposed it to infer from an ambiguous surveillance videotape of a convenience store killing that the defendant intended to murder the victim (GoodmanDelahunty, Greene, \& Hsiao, 1998). And an analysis of survey responses to an edited version of the dashboard camera videotape at issue in Scott v. Harris (2007) showed that black and politically liberal respondents were significantly more likely than whites and conservatives to disagree with the Supreme Court and find that the driver was not posing enough of a threat to public safety to justify the police's use of deadly force (Kahan, Hoffman, \& Braman, 2009).

Videotaped testimony. The effects of videotaped testimony, remote live testimony presented through videoconferencing or closed-circuit television technology, and videotaped confessions have been addressed in more studies. These are not "visual evidence" in the sense used elsewhere in this article (they are not demonstrative evidence but, rather, a mediated presentation of the testimony itself), but they do constitute another way in which using visual technologies in court may affect legal decision making. In criminal cases, the use of videotaped or remote testimony can raise the constitutional issue of a defendant's right to confront his accusers (e.g., Maryland v. Craig, 1990), and so the topic is of considerable interest to both legal scholars and psychologists. In several early studies, it was found that presenting testimony on videotape, as opposed to live, did not affect mock jurors' verdict preferences (or their ability to detect deception on the part of witnesses, another topic of special concern to researchers and legal scholars; for a review, see Hartmus, 1996). More recent research has largely confirmed these basic findings (e.g., Goodman et al., 1998).
Computer animations. Computer animations or simulations recreating litigated events (e.g., plane crashes, vehicular collisions, slip-and-falls) seem to have been of particular concern to judges and legal scholars, perhaps because they were among the first forms of computergenerated visual evidence to be introduced or perhaps because their potential for misleading viewers seems more obvious than that of photographs or videos. Of the several experimental studies of computer animations, some have shown effects on judgments of liability or responsibility (M. A. Dunn, Salovey, \& Feigenson, 2006, Study 1; Houston, Joiner, Uddo, Harper, \& Stroll, 1995; Kassin \& Dunn, 1997) or damage awards (M. A. Dunn et al., 2006, Study 1), whereas others have not (Bennett, Leibman, \& Fetter, 1999; Dahir, 2005; M. A. Dunn et al., 2006, Study 2; Ray, 2001; Rosado, 1998).

PowerPoint. Two unpublished studies of the effects of PowerPoint on legal decision making have yielded similarly mixed results. In one, the plaintiffs' use of PowerPoint slides featuring graphs illustrating statistical evidence increased the defendant's judged responsibility in a civil case (Park \& Feigenson, 2009); in the other, text slides summarizing expert testimony had no effect on judgments of guilt (Binder, 2006).

\section{Limitations of the Research}

Why has the research to date not provided stronger support for the intuitive hypothesis that visual evidence should affect ultimate legal judgments? Part of the explanation is simply that there are so few studies. Given the vagaries of experimental research, it may be premature to expect clear patterns to emerge, and any inferences from even less equivocal findings to broad claims about real-world effects would have to be tentative. The methodological limitations of various studies may also be partly responsible (for a review of methodological issues in computer animation studies, e.g., see Dahir, 2005). For instance, where visual evidence was expected to affect outcomes by increasing recall and understanding of key information, the case materials may have been so simple that participants could comprehend them well enough without visual aids, so that the demonstratives made no difference. In some, the visuals may not have been of sufficiently high quality to influence participants' thinking or may even have elicited responses contrary to those that the researchers had intended.

It is also worth emphasizing that the most important factor in juror decision making is the strength of the evidence (Eisenberg \& Wells, 2002; Visher, 1987). Consequently, significant effects on dichotomous outcome variables (guilt/innocence, liability/no liability) should be expected only when the other evidence is closely balanced, which it was sometimes not (e.g., Kassin \& Garfield, 1991).

Finally, the mixed results may indicate the presence of moderating factors. That more consistent effects have been obtained for crime scene or autopsy photos on judgments of guilt than for, say, computer animations on judgments of liability may reflect the importance of media type (i.e., photorealistic pictures as opposed to comparatively ab- 
stract animations). Another possible moderator, identified in some computer animation studies, is the familiarity of the case scenario: Animations tend to affect judgments only when the subject matter is generally unfamiliar to participants (see, e.g., M. A. Dunn et al., 2006). A further pattern that may be emerging is that visual evidence seems likeliest to affect ultimate judgments when only one side uses that evidence (M. A. Dunn et al., 2006, Study 1; Park \& Feigenson, 2009).

\section{EFFECTS OF VISUAL EVIDENCE ON JUDGMENT PROCESSES}

To refine these speculations regarding potential moderators of visual evidence effects, we need to explore the mental processes through which visual displays may affect judgments and, hence, to examine potential mediating effects. Lawyers and judges (and legal scholars) should be especially interested in identifying these processes: Because evidence may not be admitted if the trial judge determines that its probative value is substantially outweighed by any risk it may pose of unfair prejudice to the opposing party or of misleading or confusing the jury (Federal Rules of Evidence, 2009), it is important to know whether visual evidence exerts influence on ultimate judgments (when it does) in ways that tend to enhance or impair decision making.

\section{Beneficial Effects}

General psychological research suggests that visual evidence would sometimes improve legal judgment. For instance, visual displays can (as was noted above) enhance jurors' attention and recall (Bell \& Loftus, 1985), which would be predicted to improve their ultimate judgments. Visuals can also increase jurors' level of engagement, motivating them to decide more accurately (see Chaiken, 1980). Dual-coding theory (Paivio, 1971, 1986) predicts that by appealing more directly to the visual processing channel, visual evidence may help people whose learning style inclines toward the visual to understand trial information better (R. Dunn, 2000; Mayer, 2001). Charts and diagrams can improve viewers' comprehension of quantitative information; moving animations can improve their grasp of dynamic processes, especially when accompanied by an oral narration (Mayer \& Sims, 1994), as would typically be the case in court.

\section{Experimental Findings}

Recall. Exposure to visual displays has sometimes been shown to improve mock jurors' recall of key evidence (Binder, 2006, Study 2; Dahir, 2005; Morell, 1999). Other studies, however, have shown mixed effects on recall (Park \& Feigenson, 2009) or none (Houston et al., 1995). And in none of the studies in which improved recall was found did the visual evidence affect ultimate judgments of liability, so improved recall could not be a mediator.

Understanding. Computer animations sometimes appear to enhance mock jurors' ability to visualize (M. A. Dunn et al., 2006, Study 1; but cf. Ray, 2001, Study 2) and thus to understand key events. This may help explain why animations tend to affect liability and/or damage judgments only in cases in which the disputed factual issue is relatively unfamiliar-for example, a plane crash (Houston et al., 1995), the effects of a plane crash on the housing of a communication device inside the plane (M. A. Dunn et al., 2006, Study 1), or the effects of a vehicular collision on the shoulder harness of a child safety seat (Rosado, 1998). When confronting more familiar scenarios, jurors think that they can visualize events well enough on the basis of the other evidence (e.g., a car crash; Bennett et al., 1999; M. A. Dunn et al., 2006, Study 2; Ray, 2001, Study 1), so the animation does not make a difference. Visualization, however, has not yet been shown to mediate the effect of animations on ultimate judgments in unfamiliar scenarios (M. A. Dunn et al., 2006, Study 1), nor has familiarity yet been directly manipulated as an independent variable. In one other study, it was found that multimedia (video, animation, and text) improved understanding of scientific evidence only for those with a visual learning preference (Hewson \& Goodman-Delahunty, 2008). In summary, the research to date has shown relatively few beneficial effects.

\section{Detrimental Effects}

Visual evidence would also be predicted to have detrimental effects on legal judgment. For example, it might decrease judgmental accuracy by inviting jurors to decide on the basis of peripheral cues rather than the content of the message (elaboration likelihood model of persuasion; Petty \& Cacioppo, 1986). Jurors might infer from the lawyer's use of a visual display, for instance, that the lawyer is especially likeable or well prepared and might use that inference as a heuristic for the strength of the argument that the lawyer is presenting (see Petty \& Wegener, 1999). Particular kinds of demonstrative evidence may function as issue-specific peripheral cues. For example, illustrating an article about cognitive neuroscience research with brain images was shown to lead participants to rate the article as better reasoned than when the article was accompanied by a bar graph or no illustration (McCabe \& Castel, 2008). At the same time, jurors may use visual displays in ways that could bias their processing of the message's content. For example, decision makers may be more inclined to think that trial information presented visually is truthful just because they can process it more easily than they can the same information presented in verbal form (Winkielman, Schwarz, Reber, \& Fazendeiro, 2003). Perhaps most important, visual displays may be especially powerful elicitors of emotionally charged mental imagery (Kosslyn, 1994) that can bias ultimate judgments.

\section{Experimental Findings}

In a number of studies, it has been found that visual evidence may affect decision making by eliciting undue emotional responses, cognitive or perceptual biases, or reliance on peripheral cues.

Emotional impact. When mock jurors in a criminal case study saw gruesome autopsy or crime scene pho- 
tos, for instance, they became more anxious, anguished, disturbed, and shocked (Douglas et al., 1997) or angry (Bright \& Goodman-Delahunty, 2006), and mediational analyses showed that these negative emotions made them more likely to vote to convict the defendant. In one negligence case study, mock jurors' negative emotional responses to a video reenactment of a child's drowning were correlated with lesser attributions of responsibility to the plaintiff, but it was not shown that the emotional responses mediated those attributions (Fishfader et al., 1996).

Cognitive and perceptual biases. Studies of the visual hindsight bias - the "saw it all along" effect (Harley, 2007; Harley, Carlsen, \& Loftus, 2004) - suggest that in a malpractice case, for instance, jurors who see an X-ray, knowing that the ambiguous spot on it turned out to be the tumor that killed the victim, may be likelier to believe that the defendant radiologist, who of course did not know when he read the X-ray that the spot indicated a tumor, should have seen it that way too. One study involving highway accident scenarios found that mock jurors who saw computer animations of the accidents were more susceptible to the hindsight bias than were those who saw diagrams of the scene accompanied by text (Roese, Fessel, Summerville, Kruger, \& Dilich, 2006).

Visual evidence has also been shown to trigger the perceptual bias of illusory causation, people's tendency to overattribute causality to an especially salient stimulus (Ratcliff, Lassiter, Schmidt, \& Snyder, 2006). One manifestation of this is the actor-observer effect, the tendency to ascribe one's own behavior to external or situational causes while attributing the behavior of others to internal, dispositional causes (Jones \& Nisbett, 1971). The actor-observer effect has been invoked to explain why an animation depicting a plane's descent and crash from the flight crew's point of view led mock jurors to attribute less responsibility for the crash to the flight crew (Houston et al., 1995). In that study, however, point of view was not manipulated, and so the effect was not directly tested for. A more valid and robust finding is a camera perspective bias: Mock jurors who watched a criminal suspect's videotaped confession in which only the suspect appeared on screen were significantly likelier than those who also saw the interrogator to believe that the confession was voluntary and that the suspect was guilty (Lassiter, Geers, Munhall, Handley, \& Beers, 2001; Ratcliff et al., 2006).

Peripheral processing. Demonstrative evidence can also prompt decision makers to rely on peripheral cues such as judgments about the source of the message. Mock jurors who watched an animation of a slip-and-fall accident found the expert witness whose testimony the animation illustrated to be more credible than did those who saw still slides or no visuals (Dahir, 2005). Another study showed that when the plaintiffs' lawyer accompanied his opening statement with PowerPoint slides, mock jurors judged the defendant's lawyer to be less well prepared and less persuasive and, as a result, were inclined to hold the defendant more responsible (Park \& Feigenson, 2009).

\section{Other Effects}

It is also worth observing that whatever the effects of visual evidence on legal judgments, the decision makers themselves may not be aware of them (Douglas et al., 1997; M. A. Dunn et al., 2006; Ray, 2001). This may be unsurprising to cognitive psychologists, given people's well-known inability to know their own thought processes through mere introspection (Nisbett \& Wilson, 1977), but it provides a cautionary note for lawyers, who, in order to determine whether it is worth creating a computer animation for trial, may rely on asking themselves (or focus groups) what they think the effect of the animation will be.

\section{Limitations of the Research}

It should not be inferred from these results that appropriately designed visual evidence is unlikely to lead to better legal judgment. In many of the studies to date, recall, understanding, or other related effects have simply not been measured (e.g., Bennett et al., 1999; Kassin \& Dunn, 1997), or mediational analyses have not been conducted to determine whether any such measures of improved thinking played a role in participants' ultimate judgments (e.g., Rosado, 1998). The fact, for instance, that animations consistent with the physical evidence increase the percentage of verdicts in accordance with that evidence (Kassin \& Dunn, 1997, Study 1) strongly indicates that visual displays can improve decision making. The research just has not yet adequately explained how that happens.

In summary, we have only fragmentary knowledge so far about when and how visual evidence affects legal judgments of guilt or liability and damages (cf. Williams \& Jones, 2005). Beyond the ecological validity concerns applicable to some of the experiments (e.g., impoverished stimulus materials, participants unrepresentative of real jurors, absence of deliberations), there are simply too few studies, in which the designs are too varied and dependent measures too inconsistent (and in which dependent variables of interest and/or mediational analyses are sometimes omitted), to permit confident inferences about the role of visual evidence in the processes of legal decision making.

\section{CONCLUSION: TOWARD A MODEL OF VISUAL EVIDENCE EFFECTS}

Legal decision making involves highly complex cognitive and emotional processing, and one would expect that the impacts of visual evidence would be varying and nuanced - that different kinds of visual displays would have different effects, for different reasons, under different conditions. Missing from the existing literature on visual evidence effects is a comprehensive framework that might help make better sense of the findings to date and suggest productive avenues for further research (cf. Feigenson \& Dunn, 2003). Such a model should include at least the following components:

1. Independent variables:

(a) Features of the visual evidence: medium or format (e.g., photograph, video, animation, 
PowerPoint); specific formal characteristics (e.g., still vs. moving images, color, display size; especially with regard to video and animations, speed, camera angle, and point of view)

(b) Features of the case: familiarity of scenario, complexity of other evidence, strength of other evidence going to the issue(s) to which decision makers take the visual evidence as relevant and to the case as a whole, theory of the case

(c) Features of the presentation: timing (e.g., opening statement vs. closing argument, before vs. during vs. after accompanying testimony); duration and frequency; differential use (i.e., whether the opposing party is also using comparable visual evidence on the same issue [s]); presence/absence and quality of opponent's critique or counterargument to the visual evidence; jury instructions

(d) Features of the decision maker: age, familiarity with digital visual technologies, visual versus verbal learning style, need for cognition; relevant attitudes, pre- versus postdeliberation, juror versus judge

2. Potential mediator variables: for example, recall and comprehension of trial information; ability to visualize disputed events; counterfactual generation; emotional responses to evidence and parties; evaluations of the visual evidence (e.g., vividness); evaluations of credibility, persuasiveness, and likeability of witness whose testimony the visual evidence illustrates; evaluations of credibility, preparedness, likeability, and so on, of attorneys

3. Dependent variables:

(a) Ultimate judgments (in criminal case, guilt and/or sentence; in civil case, liability, apportionment of responsibility, and damages)

(b) Confidence in judgments

(c) Ratings of importance of visual evidence to judgments

Across a sufficient number of studies, the systematic manipulation of these independent variables and measurement of potential mediators, along with appropriate statistical analyses, should permit both the elucidation of some of the basic processes involved when legal decision makers respond to visual evidence and some clarification of the factors that moderate visual evidence effects. Further research can also address newer and increasingly common forms of courtroom visual displays, including surveillance videos, graphic displays of forensic scientific information, and the ever more ambitious forms of multimedia being presented in opening statements and closing arguments (Feigenson \& Spiesel, 2009). These and other studies may integrate existing findings and contribute to the development of more comprehensive models of cognition and judgment in the context of legal deci- sion making. They may also provide guidance to judges who must weigh the various beneficial and detrimental features of visual evidence (Federal Rules of Evidence, 2009), thereby enhancing the potential of this evidence to improve rather than impair legal judgment.

\section{AUTHOR NOTE}

I thank Bobbie Spellman for the opportunity to contribute to this special issue; Veronica Dahir and Meghan Dunn, for their helpful comments on an earlier draft of the article; Spellman and Tom Busey, for their careful and insightful review of subsequent drafts; and Dean Brad Saxton, for his generous research support. Correspondence concerning this article should be addressed to N. Feigenson, Quinnipiac University School of Law, 275 Mount Carmel Ave., Hamden, CT 06518-1908 (e-mail: neal.feigenson@quinnipiac.edu).

\section{REFERENCES}

BeLl, B. E., \& Loftus, E. F. (1985). Vivid persuasion in the courtroom. Journal of Personality Assessment, 49, 659-664.

Bennett, R. B., JR., Leibman, J. H., \& Fetter, R. E. (1999). Seeing is believing; or is it? An empirical study of computer simulations as evidence. Wake Forest Law Review, 34, 257-294.

BINDER, D. (2006). The relationship between need for cognition, argument strength, and the persuasiveness of courtroom technology. Unpublished doctoral dissertation, University of Wyoming, Laramie.

Bright, D. A., \& Goodman-Delahunty, J. (2006). Gruesome evidence and emotion: Anger, blame, and jury decision-making. Law \& Human Behavior, 30, 183-202.

Bright, D. A., \& Goodman-Delahunty, J. (2009). Mock juror decision making in a civil negligence trial: The impact of gruesome evidence, injury severity and information processing route. Unpublished manuscript.

Center for Legal and Court Technology (2007). Retrieved June 23, 2009, from www.legaltechcenter.net.

Chaiken, S. (1980). Heuristic versus systematic information processing and the use of source versus message cues in persuasion. Journal of Personality \& Social Psychology, 39, 752-766.

DAHIR, V. B. (2005). The effect of presentation mode and argument quality on memory, comprehension, and decision-making: Implications for computer display usage and evidence strength in the courtroom. Unpublished doctoral dissertation, University of Nevada, Reno.

Douglas, K. S., Lyon, D. R., \& Ogloff, J. R. (1997). The impact of graphic photographic evidence on mock jurors' decisions in a murder trial: Probative or prejudicial? Law \& Human Behavior, 21, 485-501.

Dunn, M. A., Salovey, P., \& Feigenson, N. (2006). The jury persuaded (and not): Computer animation in the courtroom. Law \& Policy, 28, 228-248.

DunN, R. (2000). Capitalizing on college students' learning styles: Theory, practice, and research. In R. Dunn \& S. A. Griggs (Eds.), Practical approaches to using learning styles in higher education (pp. 3-18). Westport, CT: Bergin \& Garvey.

EisenberG, T., \& Wells, M. T. (2002). Trial outcomes and demographics: Is there a Bronx effect? Texas Law Review, 80, 1839-1875.

Federal Judicial Center/National Institute for Trial AdvoCACY (2001). Effective use of courtroom technology: A judge's guide to pretrial and trial. Washington, DC: Author.

Federal Rules of Evidence (2009). St. Paul, MN: West.

Feigenson, N., \& DunN, M. A. (2003). New visual technologies in court: Directions for research. Law \& Human Behavior, 27, 109-126.

Feigenson, N., \& Spiesel, C. (2009). Law on display: The digital transformation of legal persuasion and judgment. New York: New York University Press.

Fishfader, V. L., Howells, G. N., Katz, R. C., \& Teresi, P. S. (1996). Evidential and extralegal factors in juror decisions: Presentation mode, retention, and level of emotionality. Law \& Human Behavior, 20, 565-572.

Goodman, G. S., Tobey, A. E., Batterman-Faunce, J. M., Orcutt, H., Thomas, S., Shapiro, C., \& Sachsenmaier, T. (1998). 
Face-to-face confrontation: Effects of closed-circuit technology on children's eyewitness testimony and jurors' decisions. Law \& Human Behavior, 22, 165-203.

Goodman-Delahunty, J., Greene, E., \& Hsiao, W. (1998). Construing motive in videotaped killings: The role of jurors' attitudes toward the death penalty. Law \& Human Behavior, 22, 257-271.

Harley, E. M. (2007). Hindsight bias in legal decision making. Social Cognition, 25, 48-63.

Harley, E. M., Carlsen, K. A., \& Loftus, G. R. (2004). The "saw-it-allalong" effect: Demonstrations of visual hindsight bias. Journal of Experimental Psychology: Learning, Memory, \& Cognition, 30, 960-968.

Hartmus, D. M. (1996). Videotrials. Ohio Northern University Law Review, 23, 1-15.

Hewson, L., \& Goodman-Delahunty, J. (2008). Using multimedia to support jury understanding of DNA profiling evidence. Australian Journal of Forensic Sciences, 40, 55-64.

Houston, J. M., Joiner, C. L., Uddo, F., Harper, C., \& Stroll, A. (1995). Computer animation in mock juries' decision making. Psychological Reports, 76, 987-993.

Jones, E. E., \& NisbetT, R. E. (1971). The actor and the observer: Divergent perceptions of the causes of behavior. Morristown, NJ General Learning Press.

JosePH, G. P. (1997). Modern visual evidence. New York: Law Journal Seminars Press.

Kahan, D. M., Hoffman, D. A., \& Braman, D. (2009). Whose eyes are you going to believe? Scott v. Harris and the perils of cognitive illiberalism. Harvard Law Review, 122, 837-906.

Kassin, S. M., \& DunN, M. A. (1997). Computer-animated displays and the jury: Facilitative and prejudicial effects. Law \& Human Behavior, 21, 269-281.

Kassin, S. M., \& GARFIELD, D. A. (1991). Blood and guts: General and trial-specific effects of videotaped crime scenes on mock jurors. Journal of Applied Social Psychology, 21, 1459-1472.

KossLYN, S. (1994). Image and brain. Cambridge, MA: MIT Press.

Lassiter, G. D., Geers, A. L., Munhall, P. J., Handley, I. M., \& BeERS, M. J. (2001). Videotaped confessions: Is guilt in the eye of the camera? In M. P. Zanna (Ed.), Advances in experimental social psychology (Vol. 33, pp. 189-254). New York: Academic Press.

Maryland v. Craig, 497 U.S. 836 (1990).

MAYER, R. E. (2001). Multimedia learning. Cambridge: Cambridge University Press.

Mayer, R. E., \& Sims, V. K. (1994). For whom is a picture worth a thousand words? Extensions of a dual-coding theory of multimedia learning. Journal of Educational Psychology, 86, 389-401.

McCABE, D. P., \& CASTEL, A. D. (2008). Seeing is believing: The effect of brain images on judgments of scientific reasoning. Cognition, 107 , 343-352

MNOoKIn, J. (1998). The image of truth: Photographic evidence and the power of analogy. Yale Journal of Law \& the Humanities, 10, 1-74.

Modin, K. (2006). The impact of photographic crime scene evidence on juror verdicts, jurors' feelings of confidence, beliefs about impartiality, and emotional reactions. Unpublished doctoral dissertation, Alliant International University, San Diego.

Morell, L. C. (1999). New technology: Experimental research on the influence of computer-animated displays on jurors. Southwestern University Law Review, 28, 411-415.

Nemeth, R. (2002). The impact of gruesome evidence on mock juror decision making: The role of evidence characteristics and emotional response. Unpublished doctoral dissertation, Louisiana State University, Baton Rouge.

NisbetT, R. E., \& Wilson, T. D. (1977). Telling more than we can know: Verbal reports on mental processes. Psychological Review, 84, 231-259.
Oliver, E., \& GriffitT, W. (1976). Emotional arousal and "objective" judgment. Bulletin of the Psychonomic Society, 8, 399-400.

Paivio, A. (1971). Imagery and verbal processes. Hillsdale, NJ: Erlbaum.

PaIvio, A. (1986). Mental representations: A dual coding approach New York: Oxford University Press.

Park, J., \& FeIgenson, N. (2009). Effects of a visual technology on mock juror decision making. Manuscript submitted for publication.

Petty, R. E., \& CACiopPo, J. T. (1986). The elaboration likelihood model of persuasion. In L. Berkowitz (Ed.), Advances in experimental social psychology (Vol. 19, pp. 123-205). Orlando, FL: Academic Press.

Petty, R. E., \& Wegener, D. T. (1999). The elaboration likelihood model: Current status and controversies. In S. Chaiken \& Y. Trope (Eds.), Dual-process theories in social psychology (pp. 41-72). New York: Guilford.

Ratcliff, J. J., Lassiter, G. D., Schmidt, H. C., \& Snyder, C. J. (2006). Camera perspective bias in videotaped confessions: Experimental evidence of its perceptual basis. Journal of Experimental Psychology: Applied, 12, 197-206.

RAY, R. E. (2001). Computer animation as demonstrative evidence: Does prior knowledge matter? Unpublished doctoral dissertation, University of Nebraska, Lincoln.

Roese, N. J., Fessel, F., Summerville, A., Kruger, J., \& Dilich, M. A. (2006). The propensity effect: When foresight trumps hindsight Psychological Science, 17, 305-310.

RosADO, T. (1998). The influence of computer-generated simulations on mock juror and jury decision making. Unpublished doctoral dissertation, Northwestern University, Evanston, IL.

Scott v. Harris, 550 U.S. 372 (2007).

VISHER, C. A. (1987). Juror decision making: The importance of evidence. Law \& Human Behavior, 11, 1-17.

Weichselbaum, S. (2009, July 7). Cyclist sues NYPD for $\$ 1.5 \mathrm{M}$ after YouTube vid captures cop body slam. The Daily News. Retrieved August 14, 2009, from www.nydailynews.com/news/2009/07/07/2009 -07-07_cyclist_seeks_15m_from_city_for_body_slam.html.

Whalen, D. H., \& BlanchaRd, F. A. (1982). Effects of photographic evidence on mock juror judgment. Journal of Applied Social Psychology, 12, 30-41.

Williams, K. D., \& Jones, A. (2005). Trial strategy and tactics. In N. Brewer \& K. D. Williams (Eds.), Psychology and law: An empirical perspective (pp. 276-321). New York: Guilford.

Winkielman, P., Schwarz, N., Reber, R., \& FaZendeiro, T. A. (2003). Cognitive and affective consequences of visual fluency: When seeing is easy on the mind. In L. M. Scott \& R. Batra (Eds.), Persuasive imagery (pp. 75-89). Mahwah, NJ: Erlbaum.

\section{NOTES}

1. Demonstrative evidence is to be distinguished from real evidence (actual things involved in the case; e.g., a murder weapon). Within the class of demonstratives, courts often distinguish between illustrative evidence (e.g., drawings or computer animations, offered merely to illustrate oral testimony) and substantive visual evidence (e.g., X-rays or brain scans). The distinction between the two is irrelevant for the purposes of this article.

2. The video can be viewed online at www.supremecourtus.gov/ opinions/video/scott_v_harris.rmvb.

3. The video can be viewed online at www.youtube.com/watch? $\mathrm{v}=$ nWjSOVDyUJ4.

(Manuscript received June 23, 2009; revision accepted for publication September 24, 2009.) 